\title{
Jurnal Penelitian Fisika dan Aplikasinya (JPFA)
}

Jurnal Penelitian Fisika dan Aplikasinya (JPFA) adalah jurnal peer-reviewed yang dikelola dan diterbitkan oleh Jurusan Fisika Fakultas Matematka dan Ilmu Pengetahuan Alam (FMIPA) Universitas Negeri Surabaya (UNESA) secara periodik (1 tahun 2 kali terbit) dengan jumlah 5 artikel setiap kali terbit (10 artikel per tahun). JPFA tersedia gratis (open source) untuk seluruh pembaca dan mencakup perkembangan dan penelitian dalam bidang Pendidikan Fisika, Fisika Klasik, dan Fisika Modern, baik kajian secara teoritik, eksperimen, maupun aplikasinya, termasuk: (1) Pendidikan Fisika; (2) Fisika Instrumentasi dan Pengukuran; (3) Fisika Material; (4) Fisika Teori dan Komputasi; dan (5) Fisika Bumi

\author{
Penanggung Jawab \\ Ketua Jurusan Fisika \\ Fakultas Matematika dan Ilmu Pengetahuan Alam \\ Universitas Negeri Surabaya
}

Ketua Editor

Dr. Munasir, M.Si.

Wakil Ketua Editor

Utama Alan Deta, S.Pd., M.Pd., M.Si.

Anggota Editor

Nurita Apridiana Lestari, S.Pd., M.Pd.

Meta Yantidewi, S.Si., M.Si.

Mukhayyarotin Niswati Rodliyatul Jauhariyah, S.Pd., M.Pd.

Endah Rahmawati, S.T., M.Si.

Abdul Kholiq, S.Pd., M.T.

\section{Mitra Bebestari}

Prof. Dr. Hishamuddin Zainuddin, University Putra Malaysia, Malaysia.

Prof. Dr. Agus Subekti, Universitas Jember (UJ), Indonesia.

Prof. Dr. Arif Hidayat, M.Si., Universitas Negeri Malang (UM), Indonesia.

Prof. Dr. Wiyanto, M.Si., Universitas Negeri Semarang (UNNES), Indonesia.

Prof. Dr. Darminto, M.Sc., Institut Teknologi Sepuluh November (ITS), Indonesia.

Prof. Dr. Bagus Jaya Santosa, Institut Teknologi Sepuluh November (ITS), Indonesia.

Prof. Suparmi, Ph.D., Universitas Sebelas Maret, Indonesia

Prof. Dr. Madlazim, M.Si., Universitas Negeri Surabaya (UNESA), Indonesia.

Z. A. Imam Supardi, Ph.D., Universitas Negeri Surabaya (UNESA), Indonesia.

Tjipto Prastowo, Ph. D., Universitas Negeri Surabaya (UNESA), Indonesia.

Dr. Wasis, M.Si. Universitas Negeri Surabaya (UNESA), Indonesia.

Alamat Redaksi JPFA

Jurusan Fisika FMIPA Universitas Negeri Surabaya

Jl. Ketintang, Gedung C3 Lt. 1, Surabaya 60231

Email:.jpfa@unesa.ac.id

Laman: http://journal.unesa.ac.id/index.php/jpfa 


\section{PEDOMAN PENULISAN NASKAH UNTUK JPFA}

1. Sasaran Jurnal Penelitian Fisika dan Aplikasinya (JPFA) adalah untuk menerbitkan hasil penelitian, pemikiran,pandangan dan penyebarluasan ilmu yang orisinil di bidang Fisika dan Pendidikan Fisika.

2. Naskah untuk JPFA sangat direkomendasikan untuk dikirim secara online dengan cara registrasi dulu untuk mendapatkan username dan pasword melalui website: http://journal.unesa.ac.id/index.php/jpfa.

3. Jika dalam hal pengiriman artikel secara online mengalami kendala, artikel dapat dikirim ke alamat email:jpfa@unesa.ac.id.

4. Jenis naskah yang diterima adalah hasil penelitian dan/atau hasil tinjauan ulang (review).

5. Naskah yang dikirimkan adalah naskah yang belum pernah diterbitkan, atau tidak sedang dipertimbangkan untuk diterbitkan di penerbitan lain.

6. Naskah ditulis dalam bahasa Indonesia atau bahasa Inggris.

7. Panjang naskah keseluruhan 7-20 halaman.

8. Judul naskah ditulis dalam bahasa Indonesia (Times New Roman, ukuran 12, cetak tebal, huruf kapital untuk semua kata) dan bahasa Inggris (Times New Roman, ukuran 11, cetak miring, huruf kapital untuk semua kata) jika naskah/artikel dalam bahasa Indonesia dan sebaliknya.

9. Nama penulis (tanpa gelar) harus disertai nama dan alamat lengkap lembaga serta email masingmasing penulis.

10. Abstrak berbentuk satu alinea, terdiri atas maksimum 300 kata, serta ditulis dalam bahasa Indonesia dan bahasa Inggris. Abstrak menggunakan huruf Times New Roman, ukuran 11, cetak miring (Italic). Abstrak ini merupakan ringkasan naskah, dengan memuat deskripsi dan hasil penelitian secara jelas. Lebih detail dapat dilihat pada template naskah.

11. Di bawah abstrak wajib dicantumkan kata kunci sebanyak-banyaknya 5 buah dengan huruf miring. Kata kunci ditulis dalam bahasa Indonesia dan bahasa Inggris.

12. Naskah (pendahuluan, metode penelitian, hasil penelitian dan diskusi) menggunakan huruf Times New Roman ukuran 12, spasi 1, ukuran kertas A4 $(210$ x $297 \mathrm{~mm})$ dengan margin $2.25 \mathrm{~cm}$ pada setiap sisinya kecuali sisi kiri sebesar $2.5 \mathrm{~cm}$. Lebih detail dapat dilihat pada template naskah.

13. Istilah dalam bahasa asing ditulis cetak miring jika naskah/artikel dalam bahasa Indonesia.

14. Alinea ditulis rata kiri-kanan (justify). Antar alinea diberikan jeda/spasi 1.

15. Judul gambar menggunakan huruf Times New Roman ukuran 10, rata tengah, spasi 1 dan diletakkan di bagian bawah gambar.

16. Jika mengutip gambar, tabel, atau foto dari penerbitan lain, penulis wajib menyebutkan sumber dan mendapatkan ijin dari penulis asal. File gambar dalam format .jpg, .bmp, atau .png harus dilampirkan dalam file terpisah dengan file artikel.

17. Tabel diketik 1 spasi, tanda desimal digunakan sebagai rujukan posisi (alignment) dan angka nol dicantumkan (misalnya: 0.333 dan bukan .33). Kolom dan baris tabel harus diberi judul. Judul berhuruf kapital untuk huruf pertama setiap kata, selaras dengan tata bahasa Indonesia. Judul tabel diletakkan di bagian atas tabel. Ukuran huruf 10 atau menyesuaikan. Contoh tabel dapat dilihat pada template naskah.

18. Diagram/skema/bagan/flowchart menggunakan huruf Times New Roman, spasi 1. Ukuran huruf 10 atau menyesuaikan.

19. Rumus-rumus diberi nomor urut dengan angka arab di sebelah kanan dalam tanda kurung. Hendaknya menggunakan satuan Sistem Internasional (SI) dan singkatan bakunya. Tanda desimal menggunakan tanda titik (contoh: 0.5). Singkatan hendaknya dihindari, kecuali jika telah didefinisikan sebelumnya atau merupakan suatu singkatan yang sudah umum dipakai. Catatan kaki tidak diperkenankan.

20. Pustaka diletakkan pada akhir naskah, pustaka diberi nomor urut dengan angka arab dan dirujuk dalam naskah dengan mencantumkan nomor dalam kurung kotak, contoh: "[1]". Penomoran pustaka selaras dengan urutan perujukannya untuk pertama kali dalam naskah. Adapun contoh penulisan daftar pustaka dapat dilihat pada template naskah.

21. Naskah akan dinilai oleh (minimal) dua penilai (mitra bestari) secara tertutup (blind-peer review) yang ditetapkan oleh Editorial Board (Tim Editor). Kriteria penilaian meliputi kebenaran isi, derajat orisinalitas, kejelasan uraian, dan kesesuaian dengan sasaran jurnal.

22. Tim editor berwenang untuk mengembalikan naskah untuk direvisi dan/atau menolaknya.

23. Template naskah dapat diunduh di laman http://journal.unesa.ac.id/index.php/jpfa. Keterangan lebih lanjut dapat menghubungi Dewan Redaksi via email jpfa@unesa.ac.id. 


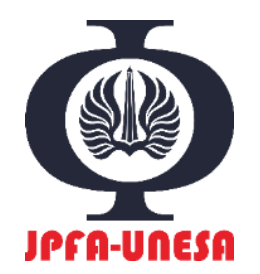

Jurnal Penelitian Fisika dan Aplikasinya (JPFA)

PENGEMBANGAN APLIKASI BERBASIS MATLAB UNTUK MENGANALISIS SIFAT LASING KACA Te-Zn-Bi YANG TERDADAH ION $\mathrm{Er}^{3+}$

BELIMBING WULUH (Averrhoa Bilimbi) SEBAGAI SUMBER ENERGI DALAM SEL GALVANI

Sri Suryaningsih

KAJIAN EKSPERIMENTAL EFISIENSI DAN KARAKTERISTIK PRODUKSI OZON BERDASARKAN VARIASI PANJANG DAN LAJU ALIR REAKTOR DIELECTRIC BARRIER DISCHARGE PLASMA (DBDP) BERBAHAN BAJA ANTI KARAT

IMPLEMENTASI MODEL PEMBELAJARAN KOOPERATIF TIPE TAI (TEAM ASSISTED INDIVIDUALIZATION) UNTUK MENINGKATKAN HASIL BELAJAR FISIKA SISWA SMA PADA MATERI ELASTISITAS

Weni Susanti dan Budi Jatmiko

WORKSHOP PENINGKATAN KEMAMPUAN MERANCANG KEGIATAN

LABORATORIUM BERORENTASI PADA PENDEKATAN SAINTIFIK BAGI GURU FISIKA SIDOARJO

Setyo Admoko dan Supriyono 